\title{
Phenology of African mahogany plants submitted to irrigation
}

\author{
Derblai Casarolii, Flávio de Oliveira Rosa', \\ José Alves Júnior', Adão Wagner Pêgo Evangelista'
}

'Federal University of Goiás, Goiânia, GO, Brazil

*Corresponding author, e-mail: derblai@ufg.br

\begin{abstract}
In the searching of forest species with good wood quality, easy adaptability and high commercial value, the African mahogany (Khaya ivorensis Chev. A.) have been a good alternative. This study aimed evaluate the phenometric responses of African Mahogany submitted to irrigation. The field experiment was carried out in Bonfinópolis-GO, Brazil, with young plants of African mahogany, being 5 irrigated and 5 non-irrigated. The following variables were evaluated: plant height, stem heigh, number of leaves and leaflets, stem diameter and leaf area. A completely randomized design was used in a bi-factorial scheme $2 \times 9$ (A: irrigated and non-irrigated; D: 0 , $120,180,240,300,360,420,480,540$ days after transplanting). All the variables showed significant differences not only for irrigated and non-irrigated treatments but also for the times of evaluation, except for stem diameter. Irrigation resulted in higher growth of plants and the irrigation of young African mahogany plants should be used mainly in drought period.
\end{abstract}

Keywords: Brazilian Savanna, edaphoclimatic conditions, plant growth, water stress, Khaya ivorensis Chev. A.

\section{Introduction}

In the last decades, forest plantations have stood out as an alternative for the recovery deforested, altered and degraded areas. Studies on technical, economic and financial viability for the planting of African mahogany (Khaya ivorensis A. Chev.) show that the species can contribute to the Brazilian economy by generating better opportunities for rural activities and national and international income, since it can provide a significant financial return, when compared to other forest species (Gomes, 2010; Danquah et al., 2011).

One of the reasons for the introduction of African mahogany in Brazil is its resistance to one of the main pests that attacks the native mahogany (Swietenia macrophylla King), named meliaceae shoot borer (Hypsipyla grandella Zeller - Lepidoptera: Pyralidae ), whose larvae destroy the apical region of the host plant and cause deformation and scraping, resulting in wood depreciation (Newton et al., 2007, OpuniFrimpong et al., 2008). In Brazil, the cultivation of the exotic meliaceae replacing mainly the native Amazon mahogany (Swietenia macrophylla King) is recommended by research and teaching institutions (Falesi \& Baena, 1999; Castro et al., 2008), while an ecological management program for $\mathrm{H}$. grandella is not established.

Due to the recent introduction of African 
mahogany cultivation in Brazil, when compared to other countries, such as Costa Rica, there is a lack of conclusive studies evaluating the economic viability of forests planted with this plant species, as well as their social and economic benefits and e environmental impacts. However, it is currently estimated the amount of one million of trees planted, mainly in the Pará State, in the Amazon, being this crop, in general, associated with silvopastoral systems, agroforestry or in homogeneous plantations, aiming the wood exportation (Gomes, 2010, Albuquerque et al., 2013).

On the other hand, in regions submitted to water deficiency, the growth of this species is limited, as it interferes by altering its metabolism (Albuquerque et al., 2013; Barkla et al., 2013). Seasonal water deficit can exert a marked effect on seedlings and young plants, whose root systems would be more exposed to water scarcity in the superficial layers of the soil, characterizing the dry season (Lambers et al., 2008; Chaves et al., 2009).

Although rainfall in the Cerrado of the Goiás State is greater than 1,400 $\mathrm{mm}_{\text {year }}{ }^{-1}$, higher than the need for average irrigation $(1200 \mathrm{~mm}$ year $^{-1}$ ) for some tree species, it is expected that African mahogany plants, when submitted to irrigation, during drought period in the Cerrado, present higher growth and development than non-irrigated plants, allowing an earlier cut.

Thus, the aim of this study was to evaluate the phenometric responses of African mahogany young plants submitted to irrigation.

\section{Material and Methods}

The experiment was carried out in the experimental area of the Mudas Nobres Company, located in Bonfinópolis-GO, Brazil (16 35 '49 "S, 49 16' 39" W, 780 m of altitude). The climate of the region, according to Köppen, was classified as Aw, tropical savannah, megathermic. The average minimum temperature is $14.3^{\circ} \mathrm{C}$ and the maximum temperature is $31.5^{\circ} \mathrm{C}$, with an average annual temperature of $23.0^{\circ} \mathrm{C}$. The average annual radiation is $2,319 \mathrm{~h}$. The pluvial regime is well defined, covering a rainy period (October to April) and a dry season (May to September), with an average annual rainfall of $1,487 \mathrm{~mm}$. The annual average for relative air humidity (UR) is $71 \%$, with August being the driest month (UR $=49 \%$ ). The average annual evaporation measured by Class A tank is 1,915 $\mathrm{mm}$. The strongest winds (average $7 \mathrm{~km} \mathrm{~h}^{-1}$ ) occurs in the month of August (Silva et al., 2007).

The soil is a dystrophic Red Latosol, with clay texture, evergreen cerrado (Brazilian savannah) with a flat relief (Silva et al., 2007). Before sowing, the soil and chemical analysis were carried out at the depths of $0.0-0.20 \mathrm{~m}$ and 0.20 $0.40 \mathrm{~m}$. After the analysis, the standards of 'Bulletin 100 ' for liming and fertilization of the area were followed, incorporating an amount of dolomitic limestone sufficient to raise the base saturation to $70 \%$ three months before planting (December 2011). The fertilization of planting was of $100 \mathrm{~g}$ $\mathrm{P}_{2} \mathrm{O}_{5}$, per hole, using the simple superphosphate. In addition, six cover fertilizations were carried out on every two months with $50 \mathrm{~g}$ of $\mathrm{NH}_{4} \mathrm{SO}_{4}$ and 25 of $\mathrm{KCl}\left(450 \mathrm{~g}\right.$ of plant ${ }^{-1}$ year-1).

The seedlings were transplanted on March 6, 2012, containing one plant per hole, with dimensions of $0.30 \times 0.30 \times 0.30 \mathrm{~m}$ and plant spacing of $5 \times 5 \mathrm{~m}$, totaling 50 plants, in a 4 ha planted forest area. At the planting the plants were 30 days old and had averages of diameter, total height and height of stem of $8 \mathrm{~mm}, 0.75$ $\mathrm{m}$ and $0.32 \mathrm{~m}$, respectively. The plants were produced in using seeds from the Para State, Brazil. The area was prepared with a plowing and two harrowings, subsoiling the planting line. Before application, the herbicide Glyphosate (3 L.ha-1) was applied. Right after the planting, a manual irrigation was done (5 L.plant $\left.{ }^{-1}\right)$. Almost two months after planting a conventional sprinkler irrigation system was installed, replacing water according to the crop evapotranspiration. Irrigation management was done through the atmospheric water demand, estimated by the reference evapotranspiration $\left(\mathrm{ET}_{0}\right)$, by the Thornthwaite Camargo method, in the first year of cultivation; however, for the second year the $\mathrm{ET}_{0}$ was determined by Penman-Monteith ( FAO Standard). This was due to the lack of meteorological data, since the automated station (Davis Vantage PRO2) was installed at the second year, collecting data on minimum and maximum temperature, solar radiation, relative 
air humidity, wind speed and rainfall. In the first year of evaluation, only air temperature, relative humidity and rainfall were obtained, from a digital thermo-hygrometer and a rain-gauge.

In the period from May, 2012 to November, 2013 the irrigated treatment was established, replacing $100 \%$ of the crop potential evapotranspiration (ETC), using the $\mathrm{KC}$ recommendation of $\mathrm{Kc}=0.5$ in the first year; $\mathrm{Kc}$ $=0.7$ in the second year (Allen et al., 1998), since there are no recommendations of these values for African mahogany plants.

Growth analyzes were performed twice a month in 10 plants, five of which were irrigated and five were non-irrigated: i) plant height (PH) - measurements from the plant soil surface to the apex; (li) stem height (SH) - measure from the soil surface to the insertion of the first leaf: (lii) stem diameter (SD) - measured $3 \mathrm{~cm}$ from the soil surface; IV) number of leaves (NL) and leaflets (NLL) - the total number of leaves and leaflets per plant were counted; $V$ ) leaf area: leaf area (LA) was estimated from leaf length $(L)$ and width (W) of the leaflets (50 leaflets per plant), in order to obtain a regression equation ( $L A=0.9223 \mathrm{LW}+294.2 ; \quad R^{2}=0,92$ ) comparing the leaf area determined by the length and width measurements, as a function of the leaf area determined by the disk method (Eq. 1):

$$
L A=[(N D \cdot A D) \cdot L T D M] / D T D M
$$

in which: LA - is the leaf area $\left(\mathrm{cm}^{2}\right), N D$ - the number of discs used, AD - the disk area, using a metallic driller with known diameter $\left(\mathrm{cm}^{2}\right)$, LTDM - leaves total dry mass G), MSTD - discs total dry mass (g); Vi) leaf expansion (LE) - length and width of 9 measured leaves per plant, 3 of each vegetative canopy extract (1/3 of upper, medium and lower). The calculation of plant growth rates was also performed.

The experiment was carried out in a completely randomized design, in a bifactorial 2x9 scheme (A: two irrigated and non-irrigated water regimes, and D: nine evaluation times- 0 , $120,180,240,300,360,420,480$ and 540 days after transplanting - DAT), with five repetitions. The data were submitted to analysis of variance by the F test, and the means were compared by the Tukey's test at $5 \%$ of error probability. The Levene test was used to test the homogeneity of the variances and the Shapiro-Wilk test for normality of the errors, both at $5 \%$.

\section{Results and Discussion}

Positive exponential equations were adjusted to the phenometric variables of the plants as a function of the nine evaluations, twice a month, indicating higher plant growth in irrigated plants, when compared to plants without irrigation (Figure 1).

This lower growth may indicate the crop sensitivity to water deficit, and it can be inferred that the plant efficiently controls water losses by regulating the stomatal opening, as already observed in young mahogany plants of other $S$. macrophylla (Cordeiro et al. 2009) and Carapa guianensis (Gonçalves et al., 2009) species, both from the same family as K. ivorensis (Meliaceae).

There was a significant interaction between irrigated and non-irrigated treatments, and evaluation times for the averages and rates of the evaluated variables (Table 1).

For all evaluations during the 18 months, no wilt or senescence of the mahogany plants were observed as according to water deficit and it can be inferred that this species has tolerance to this condition (Albuquerque et al., 2013; Chaves et al., 2009; Zhao et al., 2015).

Young plants of African mahogany have a high stomatal sensitivity to water deficiency, which, together with the proline accumulation, can lead to a moderate water stress of the species. In addition, the water status of the plants and the gas exchange are fully recovered after plants rehydration (Albuquerque et al., 2013). According to Flexas \& Medrano (2002), the lowest plant growth recorded in plants submitted to water deficit may occur due to stomatal limitation to $\mathrm{CO}_{2}$ influx, photochemical damage of the photosynthetic system, reduction in ATP synthesis, and decrease in Rubisco activity (Ribulose-1,5bisphosphate carboxylase oxygenase) or its rate of regeneration.

The treatments, irrigated and nonirrigated, showed significant differences and for the evaluation time, being the highest averages observed in irrigated plants (Table 1). Growth 

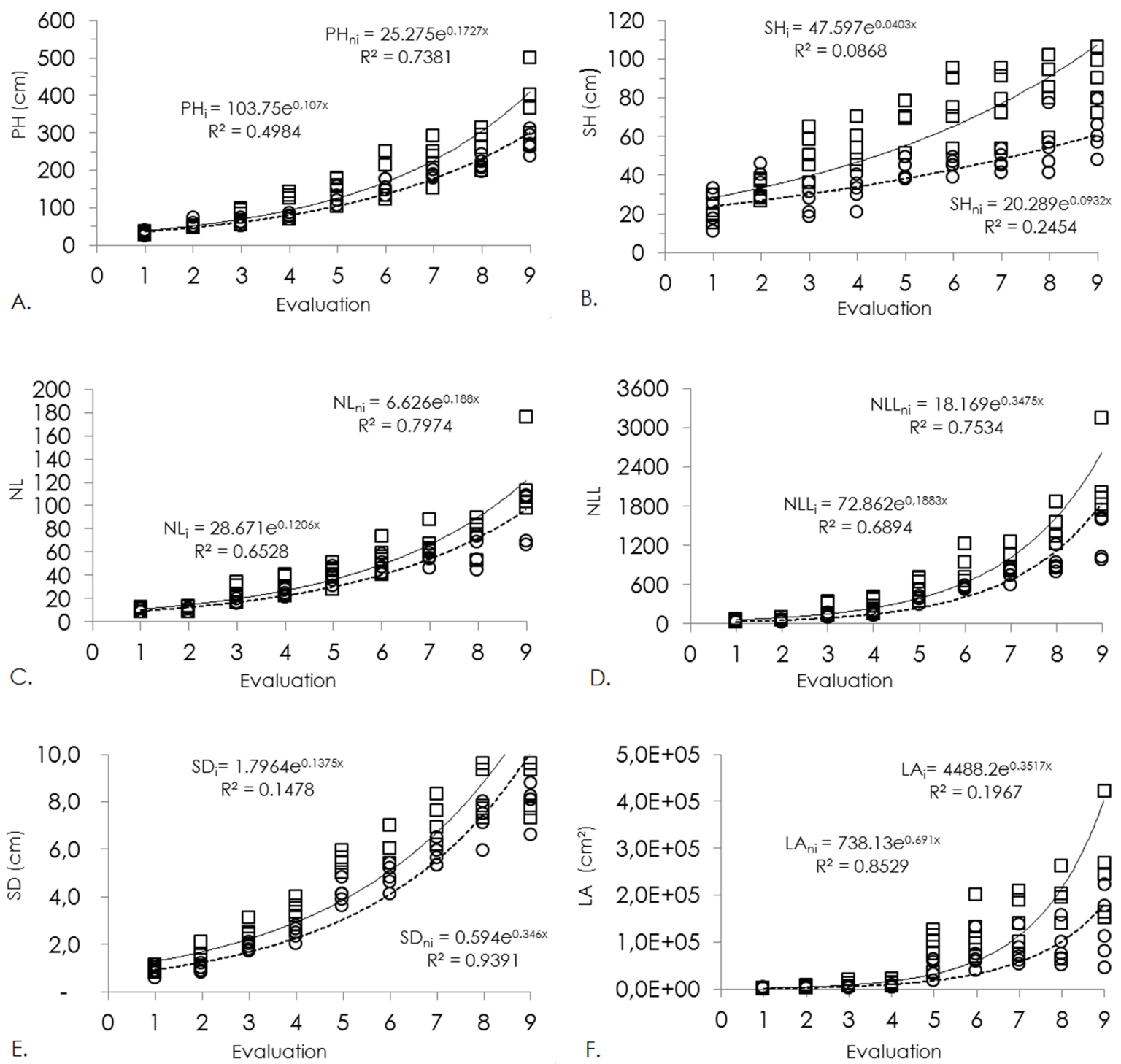

Figure 1. Biometric values for plant height (A), stem height (B), number of leaves (C), number of leaflets (D), stem diameter (E) and leaf area (F), from African mahogany, cultivated in irrigation system (subscript "i"; " $"$ " ; full line) and not irrigation (subscript "ni"; "o" ; dotted line), obtained during the first 18 months (9 evaluations, twice a month) of the forest implantation in Bonfinópolis-GO, Brazil. 
Table 1. Average of plant total height $(\mathrm{PH}, \mathrm{cm})$, stem height $(\mathrm{SH}, \mathrm{cm})$, number of leaves $(\mathrm{NL})$, number of leaflets $(\mathrm{NLL})$, stem diameter $(\mathrm{SD}, \mathrm{cm})$ and leaf area $\left(\mathrm{LA}, \mathrm{cm}^{2}\right)$, from nine evaluation performed in days after transplantation (DAT), for African mahogany irrigated and not irrigated plants. Bonfinópolis-GO, Brazil, 2012.

\begin{tabular}{|c|c|c|c|c|c|c|}
\hline DAT & $\mathrm{PH}$ & $\mathrm{SH}$ & $\mathrm{NL}$ & NLL & SD & LA \\
\hline & \multicolumn{6}{|c|}{ 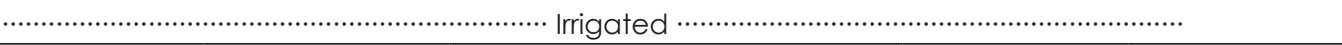 } \\
\hline 0 & $155.0 \mathrm{aB}^{*}$ & $67.4 \mathrm{aC}$ & $42.0 \mathrm{aB}$ & $576.0 \mathrm{aA}$ & $4.8 \mathrm{aD}$ & $734.5 \mathrm{aA}$ \\
\hline 120 & $156.6 \mathrm{aB}$ & $45.0 \mathrm{aC}$ & $47.8 \mathrm{aB}$ & $551.0 \mathrm{aA}$ & $5.3 \mathrm{aD}$ & $814.0 \mathrm{aA}$ \\
\hline 180 & $192.6 \mathrm{aAB}$ & $76.6 \mathrm{aABC}$ & $56.4 \mathrm{aB}$ & $884.8 \mathrm{aA}$ & $5.7 \mathrm{aD}$ & $897.3 \mathrm{aA}$ \\
\hline 240 & $219.2 \mathrm{aAB}$ & $47.0 \mathrm{aBC}$ & $55.4 \mathrm{aB}$ & $760.4 \mathrm{aA}$ & $6.0 \mathrm{aCD}$ & $900.9 \mathrm{aA}$ \\
\hline 300 & $228.4 \mathrm{aAB}$ & $78.0 \mathrm{aC}$ & $67.6 \mathrm{aAB}$ & $958.0 \mathrm{aA}$ & $7.1 \mathrm{aCD}$ & $1279.5 \mathrm{aA}$ \\
\hline 360 & $244.4 \mathrm{aAB}$ & $55.2 \mathrm{aAB}$ & $62.6 \mathrm{aAB}$ & $927.4 \mathrm{aA}$ & $7.2 \mathrm{aBC}$ & $1210.3 \mathrm{aA}$ \\
\hline 420 & $274.4 \mathrm{aAB}$ & $84.0 \mathrm{aBC}$ & $76.2 \mathrm{aAB}$ & $1361.0 \mathrm{aA}$ & $8.3 \mathrm{aBC}$ & $1727.1 \mathrm{aA}$ \\
\hline 480 & $287.6 \mathrm{aA}$ & $62.4 \mathrm{aA}$ & $91.8 \mathrm{aAB}$ & $1359.9 \mathrm{aA}$ & $8.9 \mathrm{aAB}$ & $1396.7 \mathrm{aA}$ \\
\hline 540 & $366.4 \mathrm{aA}$ & $89.4 \mathrm{aA}$ & $118.8 \mathrm{aA}$ & $2121.9 \mathrm{aA}$ & $9.1 \mathrm{aA}$ & $2495.3 \mathrm{aA}$ \\
\hline \multirow[t]{2}{*}{$\begin{array}{l}\text { Mean } \\
\text { CV\% }\end{array}$} & $\begin{array}{l}236.07 \\
24.10 \\
\end{array}$ & $\begin{array}{l}67.22 \\
20.70 \\
\end{array}$ & $\begin{array}{l}68.73 \\
26.82 \\
\end{array}$ & $\begin{array}{l}1055.60 \\
33.83\end{array}$ & $\begin{array}{l}6.93 \\
12.22 \\
\end{array}$ & $\begin{array}{l}1272.84 \\
63.56 \\
\end{array}$ \\
\hline & \multicolumn{6}{|c|}{ 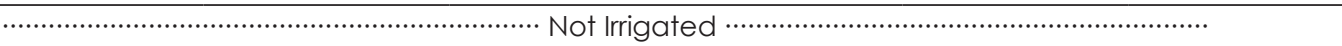 } \\
\hline 0 & $31.0 \mathrm{bD}$ & $23.2 \mathrm{bBCDE}$ & $9.2 \mathrm{bE}$ & $28.2 \mathrm{bC}$ & $0.8 \mathrm{bE}$ & $22.0 \mathrm{bc}$ \\
\hline 120 & $33.2 \mathrm{bD}$ & $20.8 \mathrm{bF}$ & $9.8 \mathrm{bDE}$ & $42.6 \mathrm{bc}$ & $0.9 \mathrm{bDE}$ & $14.5 \mathrm{bc}$ \\
\hline 180 & $55.6 \mathrm{bBCD}$ & $35.6 \mathrm{bABCD}$ & $10.0 \mathrm{bCDE}$ & $40.6 \mathrm{bC}$ & $0.9 \mathrm{bDE}$ & $30.3 \mathrm{bBC}$ \\
\hline 240 & $56.2 \mathrm{bBCD}$ & $31.6 \mathrm{bEF}$ & $11.6 \mathrm{bCDE}$ & $71.8 \mathrm{bC}$ & $1.5 \mathrm{bCD}$ & $57.2 \mathrm{bBC}$ \\
\hline 300 & $58.4 \mathrm{bBC}$ & $26.8 \mathrm{bABC}$ & 18.4 bCD & $118.6 \mathrm{bBC}$ & $1.9 \mathrm{bBC}$ & $45.8 \mathrm{bBC}$ \\
\hline 360 & $83.2 \mathrm{bBC}$ & $50.8 \mathrm{aDEF}$ & $25.6 \mathrm{bCDE}$ & 239.2 bc & $2.4 \mathrm{bB}$ & $56.5 \mathrm{bBC}$ \\
\hline 420 & $84.8 \mathrm{bB}$ & $31.8 \mathrm{bAF}$ & $23.4 \mathrm{bBC}$ & $157.8 \mathrm{bB}$ & $2.5 \mathrm{bA}$ & $116.1 \mathrm{bAB}$ \\
\hline 480 & $120.8 \mathrm{bB}$ & 55.4 aCDEF & $31.6 \mathrm{bB}$ & $310.2 \mathrm{bB}$ & $3.4 \mathrm{bA}$ & $123.6 \mathrm{bBC}$ \\
\hline 540 & $123.6 \mathrm{bA}$ & $42.0 \mathrm{aABC}$ & $38.4 \mathrm{bA}$ & $398.4 \mathrm{bA}$ & $4.1 \mathrm{bA}$ & $462.8 \mathrm{bB}$ \\
\hline Mean & 71.87 & 35.33 & 19.78 & 156.38 & 2.04 & 103.20 \\
\hline
\end{tabular}

rates were also evaluated, where a significant interaction between irrigated and non-irrigated treatments was evidenced, as well as the different evaluation times (Figure 2). Highest averages of growth rates were observed in irrigated plants for all evaluated variables, except for stem diameter (SD). On average, irrigated plants presented $\mathrm{PH}$ rates of $0.70 \mathrm{~cm}^{-d_{a y}{ }^{-1}, \mathrm{SH}}$ of $0.40 \mathrm{~cm}^{-d_{a y}{ }^{-1}, \mathrm{NL} \text { of }}$ 0.22 leaves.plant ${ }^{-1}$, NLL of 4.33 leaflets.plant ${ }^{-1}$, SD of $0.017 \mathrm{~cm}^{-d_{a y}-1}$ and LA of $80.57 \mathrm{~cm}^{-2}$.day ${ }^{-1}$. For non-irrigated plants these averages were $\mathrm{PH} 0.51$ $\mathrm{cm}$ day $^{-1}$, SH $0.11 \mathrm{~cm}^{- \text {day }^{-1} \text {, NL } 0.17 \text { leaves.plant }}{ }^{-1}$,

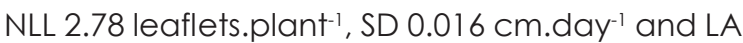
$63.27 \mathrm{~cm}^{-2}$. day $^{-1}$.

Young plants of Brazilian mahogany (Swietenia macrophylla King), cultivated in soil water contents close to the field capacity, also recorded higher values of plant height (116\%), leaf area (200\%) and stem diameter $(50 \%)$ when compared to plants in water deficit (Cordeiro et al., 2009). On the other hand, plants under water stress presented a reduction in the number of leaves and leaflets and, consequently, in the total leaf area, but no effects were detected at plant height and stem diameter (Cordeiro et al., 2009). The authors report that this can be explained by the increase of proline (400\%), minimizing the effect of drought (Cordeiro et al., 2009). Other studies, also with Khaya ivorensis, detected higher growth of plant height (23\%), stem height (28\%) and stem diameter $(21 \%)$ in drip irrigated plants compared to non irrigated plants, also in the 'Cerrado' biome of the Goias State (Barbosa, 2014).

The highest values of plant height $(\mathrm{PH})$, number of leaves (NL), number of leaflets (NLL) and leaf area (LA) were recorded in the last evaluation (540 days after transplanting - DAT). However, the highest stem height (SH) and SD rates were observed at 360 DAT and 300 DAT, respectively. The fact that the highest rates occurred for most variables in the last evaluation time may be due to the full adaptation of the plants in the area, as well as their response to rehydration (Cordeiro et al., 2009, Albuquerque et al. 2013), considering that there was an excess of water from the 10th (300 DAT) to the 15th (450 DAT) months of evaluation (Figure 3). 

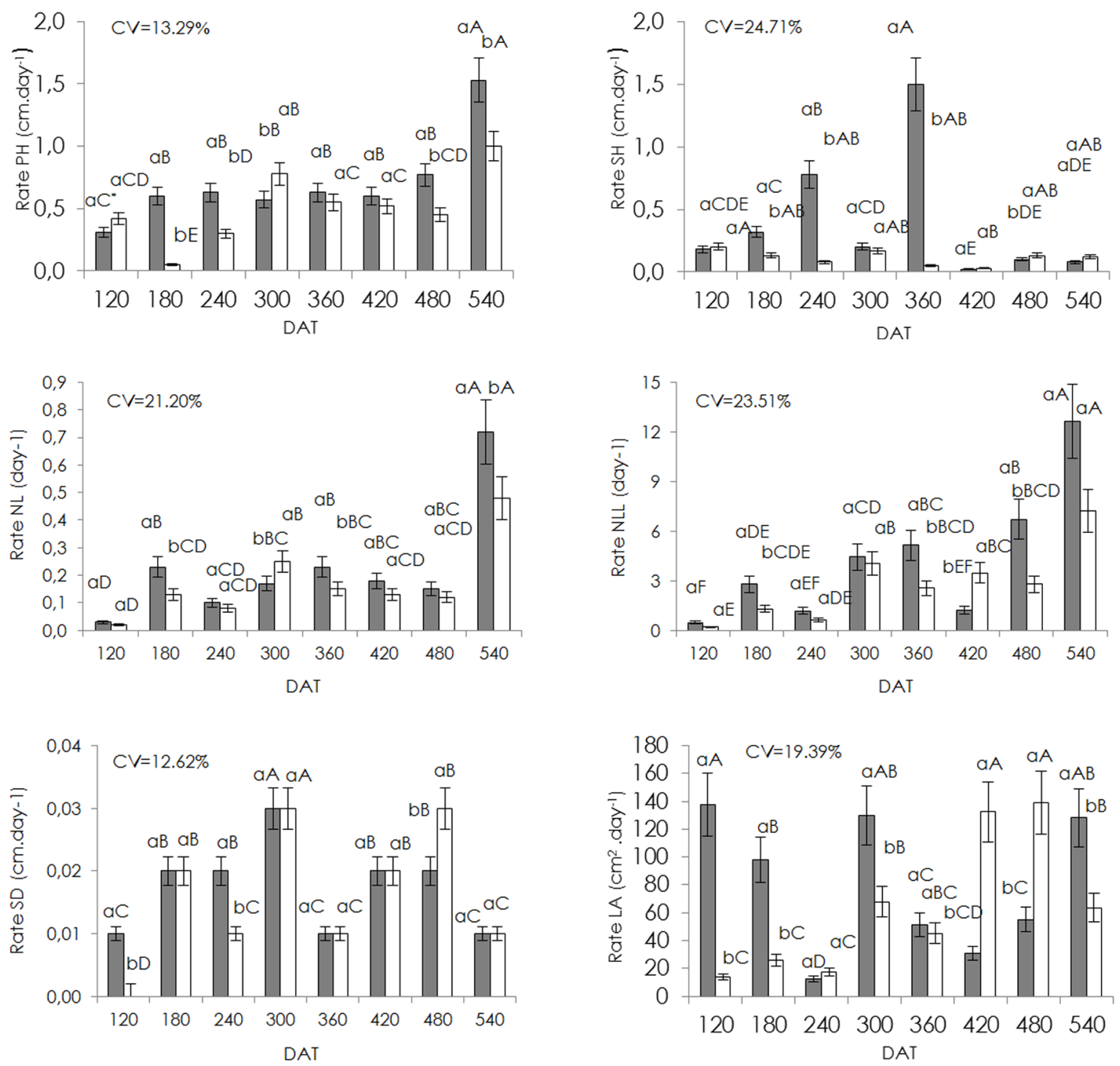

Figure 2. Rates of total plant height (Rate PH), stem height (Rate SH), number of leaves (Rates NL), number of leaflets (Rate NLL), steam diameter (Rate SD) and leaf area (Rate LA), according to the water regime (irrigated a and not irrigated $\square$ ) and times of evaluation (120, 180, 240, 300,360, 420, 480, 540 days after transplantation - DAT). "Means followed by the same lowercase letter do not differ within the evaluation time, and averages followed by the same uppercase letter do not differ in the different evaluation times

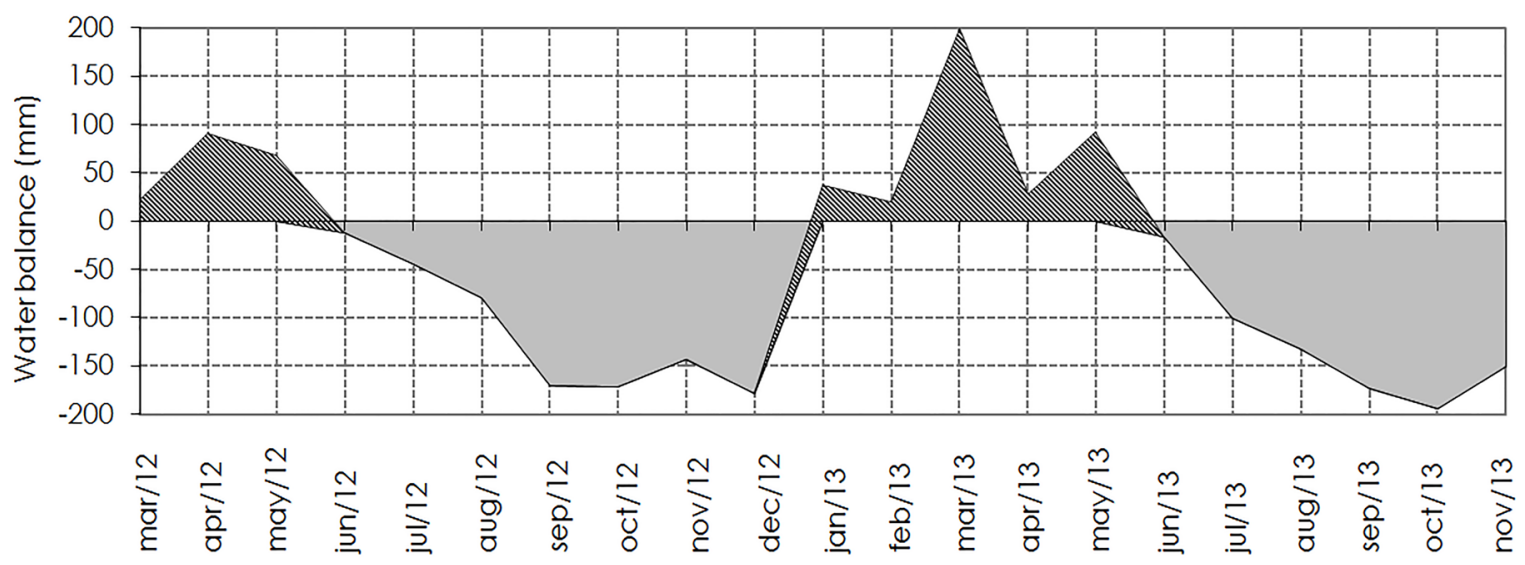

Figure 3. Climatic water balance of the experimental area (Bonfinópolis-GO) by the Thornthwaite-Camargo method, from March/2012 to November/2013, with available water capacity of $90 \mathrm{~mm}$. Stripped area correspond to the excess of water and black area is the water deficit. 
The significant interaction between water regimes (irrigated and non-irrigated) and the time of evaluation showed a difference between the growth rates according to time, with the highest averages recorded in the irrigated treatment at 540 DAP, for the rate of the variables PH, NL, NLL and LA, although some of these variables did not present significant differences in other evaluation times (Figure 2).

Periods of water deficit were recorded from July 2012 to December 2012, and from July 2013 to November 2013. Some evaluations were carried out during these periods of water deficit (120, 180, 240, 480 and 540 DAP) (Figure 3), which may explain the higher rates observed in irrigated plants for most variables. The $\mathrm{SH}$ rate also obtained the highest averages in the irrigated treatment, but at 360 DAP (March / 2013), where there no deficit was recorded (Figure 3), this may have occurred because the non-irrigated plants are recovering from a period of drought, not responding positively, even under favorable conditions of water content in the soil. Some studies confirm the cumulative effect of water stress, in which the plants submitted to the deficit may not recover their potential $\mathrm{CO}_{2}$ assimilation due to possible damages to the photochemical and / or biochemical fixation apparatus of $\mathrm{CO}_{2}$ (Shinozaki \& Yamaguchi-Shinozaki, 2007, Albuquerque et al., 2013).

The highest SD rates (Figure 2) were observed at 300 DAP (January / 2013), beginning of the rainy season in the region (Figure 3), showing no significant differences between the water regime treatments, (Figure 2), at 480 DAP (July / 2013), period of water deficit (Figure 3).

It was verified a cyclical behavior in the treatments of water regime as a function of time, being the highest averages observed for irrigated plats. Higher leaf area (LA) rates were observed in irrigated plants at 120, 180, 300 and 540 DAT, and for non-irrigated plants at 420 and 480 DAP (Figure 2). The period corresponding to the highest LA rates of irrigated plants was marked by water deficit (Figure 2 and 3), except for 300 DAP (January / 2013), when the water excess period began. This may have occurred because irrigated plants had better physiological conditions for renewal, even after a decrease in the LA rates in November / 2012 (240 DAP).

On the other hand, the highest LA rates of the non-irrigated plants were observed during periods of water deficit, between May / 2013 and July / 2013, showing that the morphological characteristics of these plants, after passing through water deficit conditions, are significantly efficient and that there is no irreversible damage to the water absorption capacity by the roots and their transport to the aerial part.

Albuquerque et al. (2013) reported that non-irrigated African mahogany plants had complete recovery of their variables indicating gas exchange $\mathrm{CCO}_{2}$ assimilation, stomatal conductance, transpiration, intercellular concentration and atmospheric $\mathrm{CO}_{2}$ ratio) within seven days after irrigation resumption. These results indicate that species can retake its photosynthetic metabolism, guaranteeing the photoassimilates production, confirmed by the values found for soluble carbohydrates on the first day after rehydration and on the remaining days of evaluation. Similar results were observed in plants of Andiroba (C. guianensis) (Gonçalves et al., 2009), Eucalyptus and Acacia spp. (Warren et al., 2011), submitted to water deficit and rehydration.

\section{Conclusions}

Irrigation of young plants of African mahogany result in higher plant growth, mainly during periods of water deficit in the 'Cerrado' biome of the Goiás State.

\section{References}

Albuquerque, M.P. F. de, Moraes, F.K.C., Santos, R.I.N., Castro, G.L.S. de, Ramos, E.M.L.S., Pinheiro, H.A. 2013. Ecofisiologia de plantas jovens de mogno-africano submetidas a déficit hídrico e reidratação. Pesquisa Agropecuária Brasileira 48: 9-16.

Allen, R.G.; Pereira, L.S.; Paes, D.; Smith, M. 1998. Crop evapotranspiration: guidelines for computing crop water requirements. Roma: FAO, 328p. (Irrigation and Drainage Paper, 56).

Barbosa, L.H.A. 2014. Irrigação em plantas jovens de mogno africano (Kaya ivorensis) no cerrado. 106f. (Dissertação de Mestrado) - Universidade Federal de Goiás, Goiânia, Brasil.

Barkla, B.J, Vera-Estrella, R., Pantoja, O. 2013. 
Progress and challenges for abiotic stress proteomics of crop plants. Proteomics 13:18011815.

Castro, A.C., Lourenço Júnior, J.B., Santos, N.F.A., Monteiro, E.M.M., Aviz, M.A.B., Garcia, A.R. 2008. Sistema silvipastoril na Amazônia: ferramenta para elevar o desempenho produtivo de búfalos. Ciência Rural 38: 2395-2402.

Chaves, M.M., Flexas, J., Pinheiro, C. 2009. Photosynthesis under drought and salt stress: regulation mechanisms from whole plant to cell. Annals of Botany 103:551-560.

Cordeiro, Y.E.M., Pinheiro, H.A., Santos-Filho, B.G. dos, Sofia S. Correa, S.S, Silva J.R.R. e, Dias-Filho, M.B. 2009. Physiological and morphological responses of young mahogany (Swietenia macrophylla King) plants to drought. Forest Ecology and Management 258: 1449-1455.

Danquah, A.J., Appiah, M., Ari, P. 2011. Ecogeographic variation in leaf morphology of african mohogany (Khaya anthotheca and Khaya ivorensis) provenance in gana. European Journal of Scientific Research 51:18-28.

Falesi, I.C., Baena, A.R.C. 1999. Mogno-africano Khaya ivorensis A. Chev. em sistema silvipastoril com leguminosa e revestimento natural do solo. Embrapa Amazônia Oriental, Belém, Brasil. 52 p.

Flexas, J., Medrano, H. 2002. Drought-inhibition of photosynthesis in C3 plants: stomatal and non-stomatal limitations revisited. Annals of Botany 89: 183-189.

Gomes, D.M. 2010. Análise de viabilidade técnica, econômico-financeiro para implantação da cultura do Mogno-Africano (Khaya ivorensis A. Chev.) na região oeste de Minas Gerais. 69f. (Dissertação de Especialização em Gestão Florestal.) - Universidade Federal do Paraná, Curitiba, Brasil.

Gonçalves, J.F. de C.; Silva, C.E.M. da; Guimarães, D.G. 2009. Fotossíntese e potencial hídrico foliar de plantas jovens de andiroba submetidas à deficiência hídrica e à reidratação. Pesquisa Agropecuária Brasileira 44: 8-14.

Lambers, H., Chapin, F., Pons, T. 2008. Plant water relations. In: Lambers, H., Chapin, F., Pons, T. (ed.) Plant physiological ecology. Springer, New York. p.163-223.

Newton, A.C., Baker, P., Ramnarine, S., Mese'n, J.F., Leaky, R.R.B. 1993. The mahogany shoot borer: prospects for control. Forest Ecology and Management 57: 301-328.

Ofori, D. A., Opuni-Frimpong, E., Cobbinah, J.R. 2007. Provenance variation in Khaya species for growth and resistance to shoot borer Hypsipyla robusta. Forst Ecology and Management 242: 438-443.

Opuni-Frimpong, E., Karnosky, D. F., Storer, A. J., Cobbinah, J. R. 2008. Silvicultural systems for plantation mahogany in Africa: influences of canopy shade on tree growth and pest damage. Forest Ecology and Management 255: 328-333.

Shinozaki, K., Yamaguchi-Shinozaki, K. 2007. Gene networks involved in drought stress response and tolerance. Journal of Experimental Botany 58:221-227.

Silva, S.C., Soares, E.G.S., Ribeiro, J.R. 2007. Informações meteorológicas para pesquisa e planejamento agrícola, referentes ao município de Santo Antônio de Goiás, GO de 2006. Embrapa arroz e feijão, Santo Antônio de Goiás, Brasil. $31 p$.

Warren, C.R., Aranda, I., Cano, F.J. 2011. Responses to water stress of gas exchange and metabolites in Eucalyptus and Acacia spp. Plant, Cell and Environment 34: 1609-1629.

Zhao, P., Liu, P., Shao. J., Li, C., Wang, B., Guo, X., Yan, B., Xia, Y., Peng, M., 2015. Analysis of different strategies adapted by two cassava cultivars in response to drought stress: ensuring survival or continuing growth. Journal of Experimental Botany 66:1477-1488. 